\title{
プラント建設における作業履歴管理システム開発とRFID の活用 \\ Development of Work Traceability System Using RFID Technology in Plant Construction Management
}

\author{
羽鳥文雄 ${ }^{1}$ ・吉村康史 ${ }^{2}$ ・ 江幡伸一 ${ }^{3}$
}

Hatori Fumio, Yoshimura Yasushi, and Ebata Shinichi

\begin{abstract}
抄録: プラント建設における管理業務の効率化を目的に, RFID の耐環境性能評価, 及び現 地での管理業務の開始となる資材管理と管理上の重要項目である作業履歴管理を対象に, RFID を応用したアプリケーションを開発した。耐環境性能評価では, 現場模擬環境下で の試験を実施し，RFID 及び位置検出に利用する GPS ともに運用を工夫することで適用可 能であると判断した。作業履歴管理については工事記録写真の問題点を整理し, デジタル 写真の真贋性を高める方法を提案した. 更に資材管理システム及び写真管理システムを開 発し，資材探索時間の削減，帳票作成時間の短縮等の効果が得られることを確認した。
\end{abstract}

\begin{abstract}
In this study, we evaluate the applicability of RFID tags and developed material management system and the work traceability system in plant construction. The examination results indicate that RFID tags and GPS systems were usable enough. About the work traceability, we solved administrative problems of the digital photographs and suggested a method to prove an original or an imitation of the digital photography. And, it was able to reduce time to search for construction materials by the developed systems and time to make a report using digital photographs.
\end{abstract}

キーワード：資材管理，出来高管理，電子タグ，G P S ，デジタルカメラ

Keywords : Material Management, Progress Management, ICtag, GPS , Digital Camera

\section{1.はじめに}

大規模プラント建設工事は取扱う製品数が多く，作 業従事者，仮設品なども膨大な数になる．建設の品質 を保証するため，工場での製作から現地での据付検査 まで，いつ・誰が・どのように実施したかを確実に把 握できるよう, 作業履歴のトレーサビリティが求めら れ，これらの管理工数は大きなものになっている。一 方で建設費の合理化要求も強く, 管理の高度化と原価 低減の相反する要求に対応することが求められている.

近年, ユビキタス社会の基盤技術となる RFID (Radio Frequency Identification）の実用化が注目されてい $3^{1)}$. 物流業界や量産工場等への適用の他, 各種実証 試験が盛んに行われている．RFID の利点は「物」に取 付けることで，取り付けた「物」の「情報」を正確に 取得できる，いわゆる「情物一体化」にある，従来は 人が介入して「物」の「情報」を取得してきたものが， RFID から直接取得できるようになる，また，バーコー ドと違い RFID のユニークコードの考えを用いれば, 部 品単位で「物」を特定できるため, 取り違いミスや情 報転記ミスなどの防止に有効な手段となる.
大規模プラント建設での大量かつ多品種の製品管理 において，RFID を利用することで確実な履歴管理（作 業トレーサビリティと称す）が確保できると考える. これまで人手を介して記録していた製品管理業務が RFID により，確実かつ簡易にできるようになり，作業 効率の向上にも寄与寸る.

志谷, 矢吹 ${ }^{2)}$ らは RFID を用い現場デジタル写真の 管理及び設計情報との連携についてプロトタイプシス テムを開発し，RFID の有效性を確認している. 情報シ ステムが実用化されるためには有用なアプリケーショ ンと共に基盤となるハードウェアの開発が必要である. RFID は日進月歩で新製品が開発されており，今後も技 術進歩は進むと考える.上記報告当時に比心゙，新たな 種類の RFID 等, 新しいハードウェアも市場に出ている. 本報告ではプラント建設への RFID 適用性検討とし て,プラント建設環境下における RFID 而環境性能評価, 及び管理業務の開始点となる現地での資材管理から管 理の重要項目である作業トレーサビリティを対象に RFID を応用したアプリケーションの開発について述 ベる.

1 ：正会員 (株) 日立プラントテクノロジー 研究開発本部 事業開発部

( $\overline{1} 170-8466$ 東京都豊島区東池袋四丁目 5 番 2 号，Tel :03-5928-8195)

2 ：非会員 博士 (工学) (株) 日立プラントテクノロジー 研究開発本部 松戸研究所

3 : 非会員 (株) 日立プラントテクノロジー エネルギーシステム事業本部 電力事業部 


\section{2. プラント建設管理と RFID 応用検討}

\section{（1）資材管理業務}

プラント建設における配管やバルブなどの製品群は, 工場で製作・出荷され，建設現場まで輸送される．現 場では，倉庫や資材置場にて一時的に保管（仮置きと 称す）され，現場の工程に合わせて建設建屋内に搬入 される。大規模プラント建設では建設工期内で膨大な 資材の物量を管理することとなり，荷受時の現品照合 には多大な管理工数がかかる。また，屋外の広大な敷 地が資材置場となることもあり，日々，流動的に変化 する資材置場では利用する段階になって製品の探索に 時間が掛かるとの問題もあった。これらの問題を解決 する方法としてRFIDの適用を検討した。

図 1 にRFIDを応用した資材管理の運用フローを示す。 製品に RFID を取付けて工場を出荷し, 現地で荷受する 際に, RFID を読取りながら荷受することで納品予定品 と現品の確実な照合が可能となる，更に，屋外資材置 場に仮置きする際に, この RFIDに製品保管位置を紐付 けて記録することで，製品を搬入する際に，製品探索 時間の短縮が図れる。

製品の保管位置を記録する方法には，GPS（Globa1 Positioning System) の利用を想定した。屋外の広範 囲な資材置場を効率的に位置計測するため，製品を保 管する位置に管理者が移動し，GPS 受信機により，管 理者が立つ位置を保管位置として記録する。搬入する 製品を探索する際には，予め仮置きの際に記録した位 置情報に基づき，現場内の保管位置を提示すれば，容 易に製品探索が可能となる.

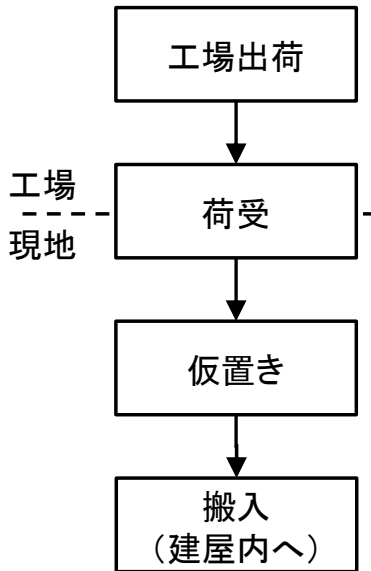

RFID取付

現品照合

\section{仮置き位置記録} (GPS利用)

\section{製品探索} (GPS利用)

図1 資材管理フロー

\section{（2）作業トレーサビリティ}

建設作業の品質を確保するために，作業履歴として， いつ・誰が・何を対象として何の作業をしたか，その時 の作業条件や検査結果を記録している.これは作業トレ 一サビリティと呼ばれ, 工事の品質保証記録になると共
に，プラント運転後に不具合が発生した場合，原因を遡 及するための手段となる。

図 2 に配管開先合せを例にした据付作業の流れとそ のときの記録内容を示す．建屋内に搬入された配管は 据付位置近傍に仮吊りされる. 次に, 配管の管内に異 物が混在してないかが確認され，異物が無いことを証 明する記録写真を残してから配管端面の開先合せが実 施される.ここでは, 開先合せの作業指示内容に従い, 誰がいつ作業を実施したかを記録する。作業完了後, 開先合せ作業が指示通りに実施されたかが立会検査に て確認・記録される，立会検査に合格すると溶接作業 が実施される. 次工程の溶接作業や配管以外の作業に ついても，作業の品質を保証するための記録を残すこ とで，作業トレーサビリティが確保される。これら管 理対象を RFID で特定し，RFID による情報入力を図る ことで，記録の効率化及び品質管理に寄与できる。

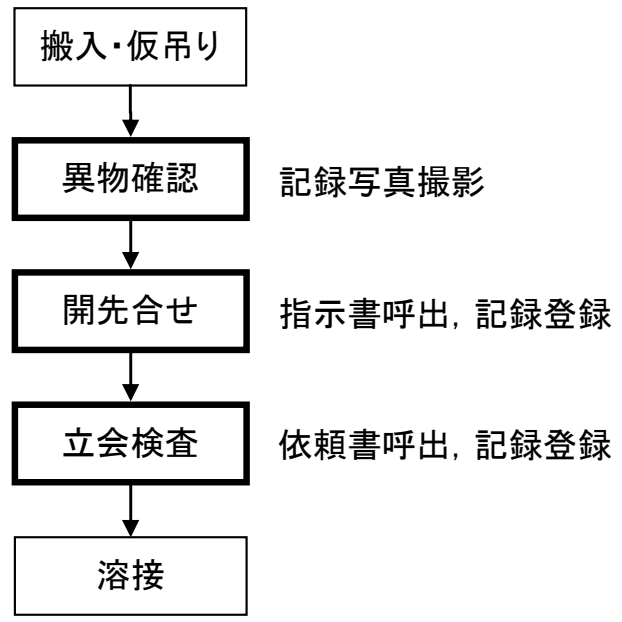

図2 配管据付作業と記録内容

\section{RFID 適用課題と検討方法}

\section{（1）耐環境性能評価}

建設現場への RFID 適用を想定し，建設現場特有の RFID 而環境性評価項目を選定した。表 2 に RFID 而環 境性評価項目と想定条件を示す。これらの条件下で RFID が壊れず読取りできること，及び RFID を利用し て業務を運用する際の問題の有無を確認した。また, 資材管理を想定すれば大量の製品に RFID を使うこと から低コストが必須となる。評価時点で購入可能な RFID の中から低コストを想定し，普及型 RFID として 表 3 に示す $13.56 \mathrm{MHz} ， 2.45 \mathrm{GHz} ， 950 \mathrm{MHz}$ の製品を選定 し，各評価項目について実験を行った。図 3 には RFID の溶接熱の影響を評価するための実験状況を示す。評 価方法としては，各評価項目について現場環境を模擬 した条件下に RFID タグを曝し，RFID リーダによりタ グ内に記録された ID の読取り可否を確認した。 
表 2 RFID 耐環境性評価項目及び想定条件

\begin{tabular}{|c|c|c|l|}
\hline No & \multicolumn{2}{|c|}{ 現場環境 } & \multicolumn{2}{|c|}{ 想定条件 } \\
\hline \multirow{2}{*}{1} & \multirow{2}{*}{ 温度 } & 高温時 & RFID近傍で溶接実施 \\
\cline { 3 - 4 } & & 低温時 & 冬季屋外 $\left(-20^{\circ} \mathrm{C}\right)$ 保管 \\
\hline 2 & \multicolumn{2}{|c|}{ ノイズ影響 } & \multicolumn{2}{l|}{ 溶接機やGPS機器近傍での利用 } \\
\hline 3 & 製品運搬 & 製品輸送·荷降し時の接触など \\
\hline \multirow{2}{*}{4} & \multirow{2}{*}{ 水分 } & 雨 & 屋外雨天時 \\
\cline { 3 - 4 } & 環境 & 雪 & 屋外降雪時 \\
\hline \multirow{2}{*}{5} & \multirow{2}{*}{ 污れ } & 鉄粉 & 建設建屋内での鉄粉首付着 \\
\cline { 3 - 4 } & & 塗装 & 塗装材の付着 \\
\hline
\end{tabular}

表 3 評価した RFID タグ

\begin{tabular}{|c|c|c|c|}
\hline 製品タイプ & $\mathrm{A}$ & $\mathrm{B}$ & \multicolumn{1}{c|}{$\mathrm{C}$} \\
\hline 周波数 & $13.56 \mathrm{MHz}$ & $2.45 \mathrm{GHz}$ & $950 \mathrm{MHz}(\mathrm{UHF})$ \\
\hline 特 徵 & $\begin{array}{l}\text {-書込み可能 } \\
\text {-通信距離 }: 30 \mathrm{~cm}\end{array}$ & $\begin{array}{l}\text {-小型, 低価格 } \\
\text {-通信距離: } 30 \mathrm{~cm}\end{array}$ & $\begin{array}{l}\text {-書込み可能 } \\
\text {-長距離通信 } \\
\text {-通信距離 }: 3 \mathrm{~m}\end{array}$ \\
\hline 外 観 & & & \\
\hline
\end{tabular}

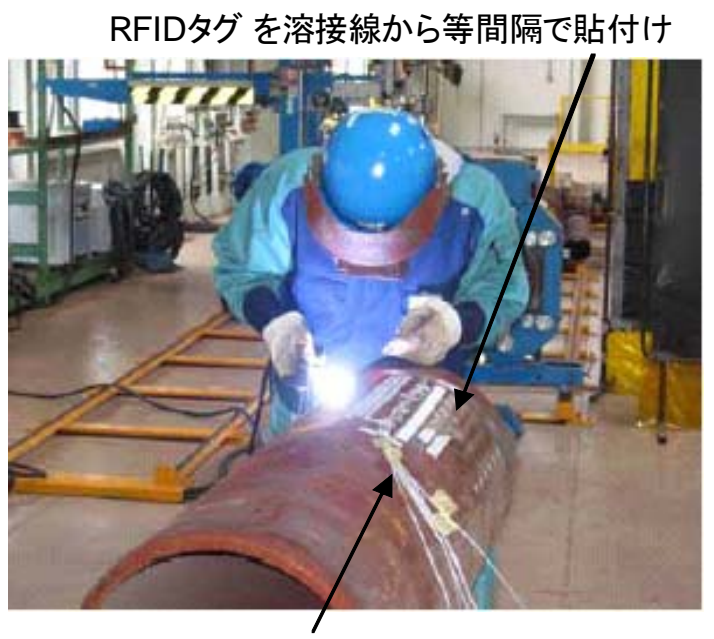

熱電対により表面温度測定

図 3 溶接熱評価試験状況

\section{（2）資材保管位置検出精度}

図 1 の資材管理フローにおいて, 製品の仮置き位置 を GPS にて測定し, 保管位置情報を RFID に紐付けて管 理した。この時に必要な位置測定精度を確認した。表 4 に管理対象と位置検出目標を示す。製品を個々（ス プールと呼ぶ）に位置検出するためには，小径配管や サポートなど形状の小さいものでは土1m の精度が必 要となる。しかし高精度で位置計測するためには，そ れに相当する機器や計測時間が必要となる.今回は, 荷受時にまとめて仮置きする単位（区画と呼ぶ）で, 短時間で簡易に測定できることを目標とし，目標精度
を $\pm 3 \mathrm{~m}$ 以下とした。計測時間については，1 回当たり の計測時間は 30 秒以下を目標とした.

表 4 管理対象と位置検出目標

\begin{tabular}{|c|c|c|c|c|}
\hline \multirow{2}{*}{ 管理対象 } & \multirow{2}{*}{$\begin{array}{c}\text { スプール単位 } \\
\text { 検出要求精度 }\end{array}$} & \multirow{2}{*}{$\begin{array}{c}\text { 画単位検出 } \\
\text { 要求精度 }\end{array}$} & \multicolumn{2}{|c|}{ 位置検出目標 } \\
\cline { 4 - 5 } & 検出精度 & 計測時間 \\
\hline 大径配管 & $\pm 3 \mathrm{~m}$ & $\pm 3 \mathrm{~m}$ & $\pm 3 \mathrm{~m}$ & 30 秒以下/回 \\
\hline 小径配管 & $\pm 1 \mathrm{~m}$ & $\pm 3 \mathrm{~m}$ & $\pm 3 \mathrm{~m}$ & 30 秒以下/回 \\
\hline サポート & $\pm 1 \mathrm{~m}$ & $\pm 3 \mathrm{~m}$ & $\pm 3 \mathrm{~m}$ & 30 秒以下/回 \\
\hline
\end{tabular}

図 4 に GPS の測定精度を評価するための実証フィー ルドの寸法及び GPS による位置測定点を示す。両側に 工場建屋があり，フィールド内に門型クレーンが一部 の範囲で稼動していた。また，建屋内では溶接機が稼 動しており, 溶接機からのノイズが建屋近傍では発生 していた. 図 4 の測定点の中で, No. 0 は比較的建設現 場の資材置場環境に近く, また, 建物から離れており, 上記溶接機ノイズの影響は受けなかった。 その他は建 屋近辺から少しずつ離した点にて観測を行い，建物の 壁の影響や建屋ノイズ等の影響について確認した。

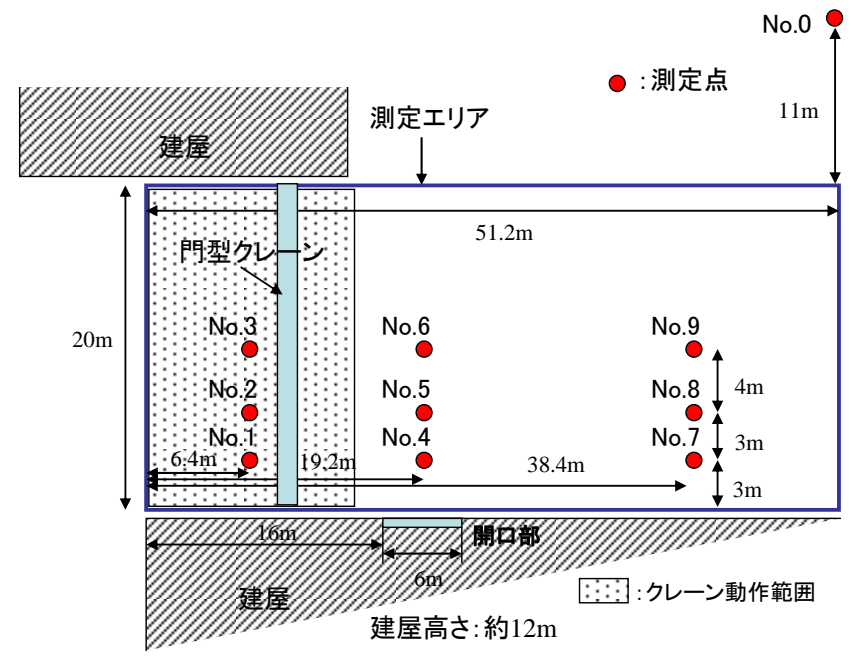

図4 試験フィールド及びGPS測定点

測定に使用した GPS は D-GPS（Differential-GPS） と呼ばれる, 電波補正により比較的簡易に高精度測定 が可能な GPS 機器を利用した. 図 5 に測定に使用した GPS 機器の仕様を示す. GPS の測定状況を示すパラメー タとして, クオリティ, 取得衛星数, HDOP (Horizontal Dilution of Precision) を確認した.クオリティには, 補正電波を受信し，高精度測位状態にある D-GPS モー ドと補正波を受信できずに GPS アンテナのみの単独測 位モードの 2 種がある. 取得衛星数は測定に利用して いる GPS の数であり，取得数が多いほど精度が高くな る. HDOP とは取得した衛星のちらばりを示すものであ り, HDOP の数值が小さいほど, ちらばりが大きく, 測 定精度が高くなる。測定には各測定点にて三脚上に GPS アンテナを固定し, 10 分間で 50 点前後を定点観測 
し，この間のデータばらつきを評価した。

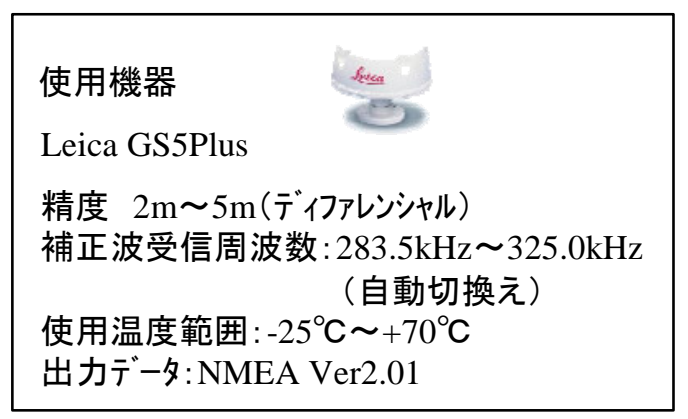

図 5 GPS 機器仕様

\section{（3）作業トレーサビリティにおける課題}

プラント建設において作業トレーサビリティの証明 として記録写真が重要な対象となる。しかし，現状の 記録写真には表 5 に示寸問題がある.

配管等, 検查対象物は類似の物が多く, どこの製品を 写しているかは, ボードに必要項目を記載し, 写真と一 緒に写すことで記録する. ボードが写っていないと記録 写真がどこの製品を撮影しているのかわからなくなっ てしまう。また, 本方式ではボードの情報と写真の情報 が同一であることを証明するのは不可能である. 更に, 写真を整理する際には写真ファイルを一つ一つ開いて, ボード情報を確認する必要があり非常に手間の掛かる 作業となっていた.

以上の問題解決を目的に, 写真の真贋証明方法の検 討, 及び写真整理及び探索時間削減に重点を置いた RFID 応用写真管理システムを開発した.

表 5 現状の写真管理に関する問題点

\begin{tabular}{|l|l|l|}
\hline 項目 & 現状 & 問題点 \\
\hline $\begin{array}{l}\text { 写真の } \\
\text { 真贋性 }\end{array}$ & $\begin{array}{l}\text { 対象物情報を } \\
\text { ボードに記載し } \\
\text { 写真に記録 }\end{array}$ & $\begin{array}{l}\text { ボード情報と写真 } \\
\text { の同一証明困難 }\end{array}$ \\
\hline $\begin{array}{l}\text { 写真整理の } \\
\text { 効率性 }\end{array}$ & $\begin{array}{l}\text { 写真の中身は } \\
\text { 画像を見て確認 }\end{array}$ & $\begin{array}{l}\text { 画像を人が見て } \\
\text { 判断 }\end{array}$ \\
\hline $\begin{array}{l}\text { 写真探索の } \\
\text { 効率性 }\end{array}$ & $\begin{array}{l}\text { エ事記録アルバムに } \\
\text { ファイルして管理 }\end{array}$ & $\begin{array}{l}\text { 特定の写真を探 } \\
\text { す手間が掛かる }\end{array}$ \\
\hline
\end{tabular}

\section{RFID 適用性評価結果とアプリケーション開発}

\section{（1）耐環境性能評価結果}

表 6 にRFID の耐環境性評価結果を示す. 図中○は RFID タグが壊れず, 通常状態での読取り性能と同等で あったことを示す. $\triangle は$ 通常状態に比べ読取り距離が 短くなったこと，×は読取り不可を示す.

いずれのタグもほとんどの項目でも壊れることなく 読取りが可能であったが，タグが水に浸ったままの状 態，タグが金属に直接接触している場合に読取り不可 になることが分かった。しかし，降雨や降雪時に屋外
で使用する場合，タグが水に浸かっても水分を払うな ごして読取れば問題なく読取れた，金属に対してはタ グ部を金属から隔離材などで数mm程度離すことで読取 れた.製品運搬についての試験では, $2.45 \mathrm{GHz}$ と 950MHz のダイポールアンテナ方式のタグはチップそのものが 壊れなければ，アンテナが切れても読取りが可能であ ったのに対し，13.56 MHz のコイル形状のタグはアンテ ナが切れただけでも読取りが不可になった．2. $45 \mathrm{GHz}$ タグはアンテナ構造も $13.56 \mathrm{MHz}$ タグに比心゙小型であ るため, 衝撃に対する影響は少ない，特に，配管等の 重量物に取付けるため, タグが大きいほど衝撃を受け る範囲が大きくなり, 壊れる可能性が大きくなる.

RFID の通信距離は, RFID 読取り装置の出力によって も影響される. 実運用を想定し低出力のハンディ型読 取り機を利用した。 その結果, 通常状態でもカタログ 值よりも読取り距離が短く $13.6 \mathrm{MHz}$ のタグで $50 \mathrm{~mm}$, 2. $45 \mathrm{MHz}$ で $30 \mathrm{~mm}, 950 \mathrm{MHz}$ でも $100 \mathrm{~mm}$ 程度であった. $\triangle$ の評価結果はこれらの半分程度の距離に落ちた時を想 定している. 通信距離に関してはカタログ值との差が 大きく, 運用上はもう少し通信距離が伸びることが期 待される.

以上の結果から, RFID は金属対応方法等で運用方法 を工夫すれば，プラント建設にも適用可能である見通 しが得られた。 但し, 製品運搬時に RFID が損傷する可 能性があること, 損傷に対してはダイポールアンテナ 方式のタグの方が比較的有効であることがわかった.

表 6 RFID 而環境性評価結果

\begin{tabular}{|c|c|c|c|c|c|c|}
\hline No & \multicolumn{2}{|c|}{ 確認環境 } & $13.6 \mathrm{MHz}$ & $2.45 \mathrm{GHz}$ & $950 \mathrm{MHz}$ & 備考 \\
\hline \multirow{2}{*}{1} & \multirow{2}{*}{ 温度 } & 高温時 & 0 & 0 & 0 & $\begin{array}{l}\text { RFID近傍 } \\
\text { 温度: } 283^{\circ} \mathrm{C}\end{array}$ \\
\hline & & 低温時 & 0 & 0 & 0 & $-20^{\circ} \mathrm{C} て ゙$ 読取り可 \\
\hline 2 & \multicolumn{2}{|c|}{ ノイズ影響 } & 0 & 0 & 0 & 溶接機, GPS \\
\hline 3 & \multicolumn{2}{|c|}{ 製品運搬 } & $x$ & $\Delta$ & $\Delta$ & $\begin{array}{l}\text { アンテナ切断時 } \\
\text { 能力低下 }\end{array}$ \\
\hline \multirow{2}{*}{4} & \multirow{2}{*}{$\begin{array}{l}\text { 水分 } \\
\text { 環境 }\end{array}$} & 雨 & 0 & 0 & 0 & 運用で対応可 \\
\hline & & 雪 & 0 & 0 & 0 & 同上 \\
\hline \multirow{2}{*}{5} & \multirow{2}{*}{ 污れ } & 鉄粉 & O & O & O & 運用で対応可 \\
\hline & & 塗装 & 0 & 0 & 0 & \\
\hline
\end{tabular}

\section{（2）資材保管位置計測精度検証結果}

GPS による位置検出精度の評価試験結果について示 す. 先に示した図 4 の測定点のうち, 特徽的な傾向が 見られた 5 点 (No. 0, No. 1, No. 3, No. 7, No. 9) につ いて測定結果を示寸.

\section{a) No. 0 測定点（基準点）}

現場環境に近い条件として周辺に建物などの障害が 無い場所を基準点として, その位置での GPS 測定精度 を確認した. 図 6 に基準点の GPS 測定結果を示す.

基準点では全ての測定について高精度測定の D-GPS モードで測定ができた. 取得した衛星数も 4 つ以上, 
HDOP も 2 以下が $99 \%$ であり, その結果, ばらつきも小 さく $\pm 1.5 \mathrm{~m}$ の精度で測定できた。

\section{b) No. 1 測定点}

図 7 に No. 1 測定点での測定結果を示す.本測定点は 2 つの建物に挟まれた場所で，特に建屋に近い点で測 定したものである。ここではばらつきが大きく，比較 的大きな測定誤差が生じている.これは, GPS の通信 信号が建屋に反射したものと考えられる。 また，建屋 内で稼動する溶接機ノイズや門型クレーンから発生す るノイズの影響で補正電波が受信できずに単独測位モ ードになってしまうことがあった。これらが相互に影 響し，大きな誤差になったと予想する.

\section{c) No. 3 測定点}

図 8 に No. 3 測定点の測定結果を示す. 本測定点は 2 つの建物の間であるが，双方の建屋からそれぞれ $10 \mathrm{~m}$ の距離があったため, 比較的反射の影響は少なかった。 しかし No. 3 と同様に補正波が受信できない状況が発 生し, ばらつきは比較的少ないが, 補正派を受信でき た場合と出来ない場合でデータに誤差が現れた.

\section{d) No. 7 測定点}

図 9 に No. 7 測定点の測定結果を示す. 本測定点は片 側にのみ建屋がある条件であるが，建屋に近いため， No. 1 と同様に建屋反射によりデータがばらついてい たと考えられる。これらの結果から GPS の測定には建 物等の大きな障害物近傍では反射の影響により, 誤差 を生じてしまうことが分かった。これは補正波の受信 の影響よりも影響が大きくなっていた.

\section{e) No. 9 測定点}

図 10 にNo. 9 測定点の測定結果を示す.本測定点は, 片側のみに建屋があるが，建屋から $10 \mathrm{~m}$ 離れた点であ る. 建物から $10 \mathrm{~m}$ 離れることで反射の影響がほとんど 受けない状態になったと考える。また，溶接機ノイズ の影響も受けず, 全て D-GPS モードでの測定となった. この位置ではばらつきも小さく, 基準点に近い条件で 測定ができていたと考える.

以上の結果から図 11 にGSS 測定精度評価結果のまと めを示す。建屋反射による影響範囲とノイズの影響に より補正波の受信に影響が出る範囲を重ねて表示した. 現場の資材置場に近い条件である無障害エリアについ ては，ばらつきも小さく今回の実験結果である $1.5 \mathrm{~m}$ 程度で測定できる見通しが得られた。但し，建物の近 くでは建屋からの反射により誤差が出る. 更に, 実験 フィールドに設置されていた門型クレーンが稼動して いる時と建屋近傍で溶接機が稼動している時には, D-GPS の補正波が受信できなかった。補正波は中波帯 で $300 \mathrm{kHz}$ 前後であり,クレーンに設置されたモータや 溶接機等が中波帯の補正波に干渉していたと推測され る. 建屋反射と補正波へのノイズの 2 つの影響が重な る部分では, 特に誤差が大きくなることが予想される.
以上から, 建屋近傍では GPS が使えないが，長期保 管する資材の多くは基準点に近い環境にあるため，こ の範囲では GPS を利用したシステムが有効と判断した。

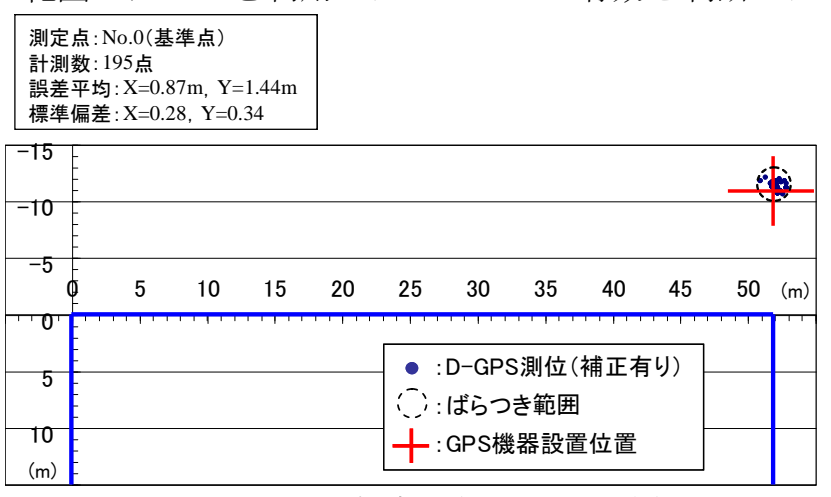

図6 GPS測定結果(No.0:基準点)

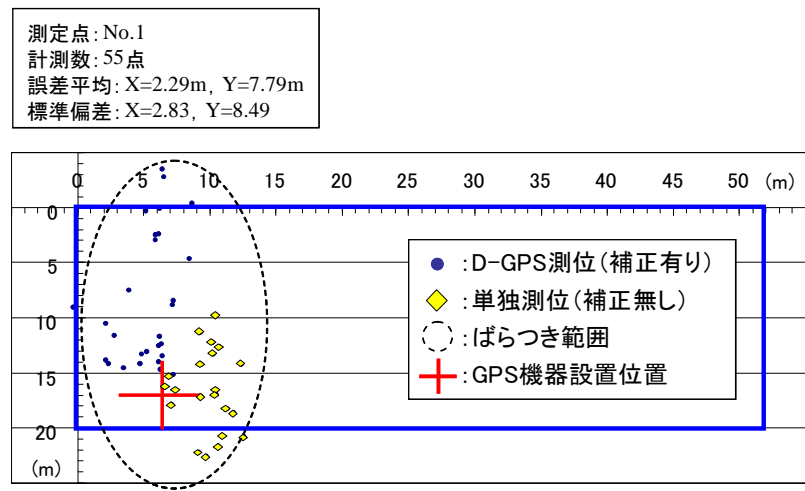

図7 GPS測定結果(No.1測定点)

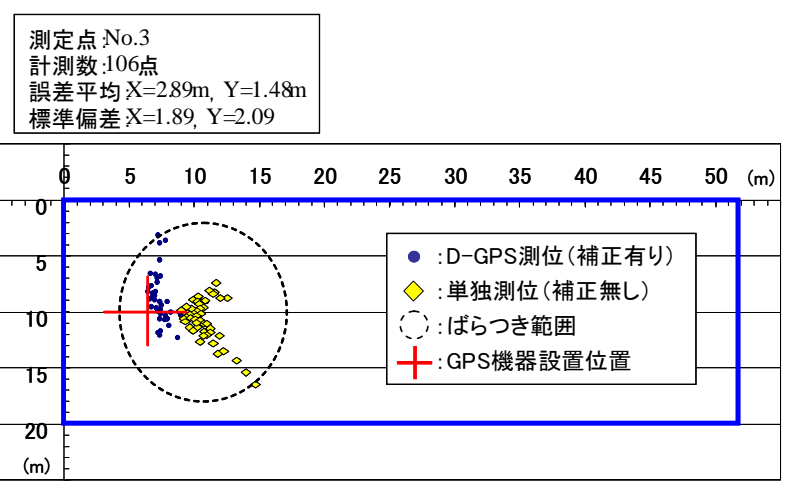

図8 GPS測定結果 (No.3測定点)

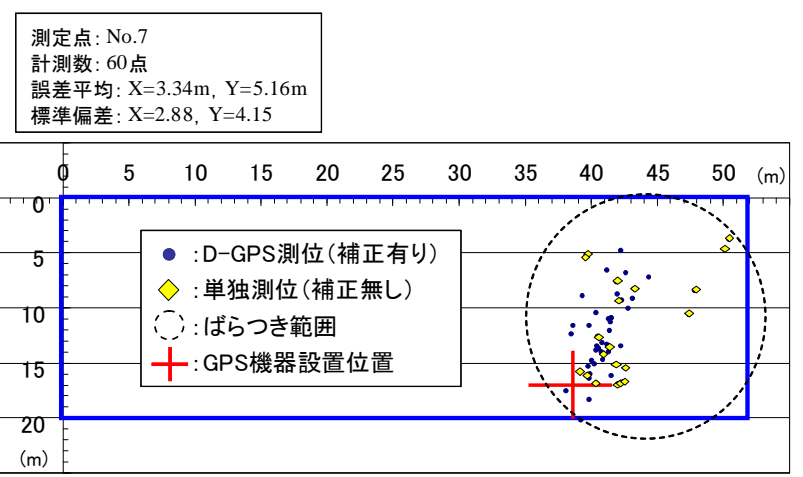

図9 GPS測定結果 (No.7測定点) 


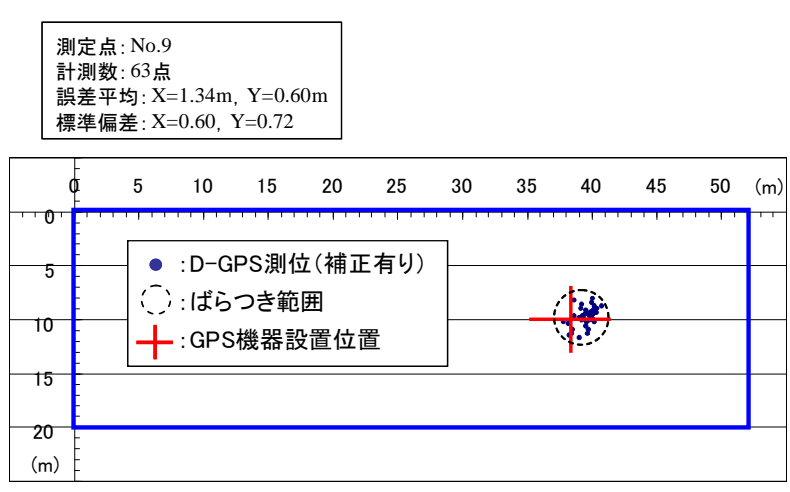

図10 GPS測定結果 (No.9測定点)

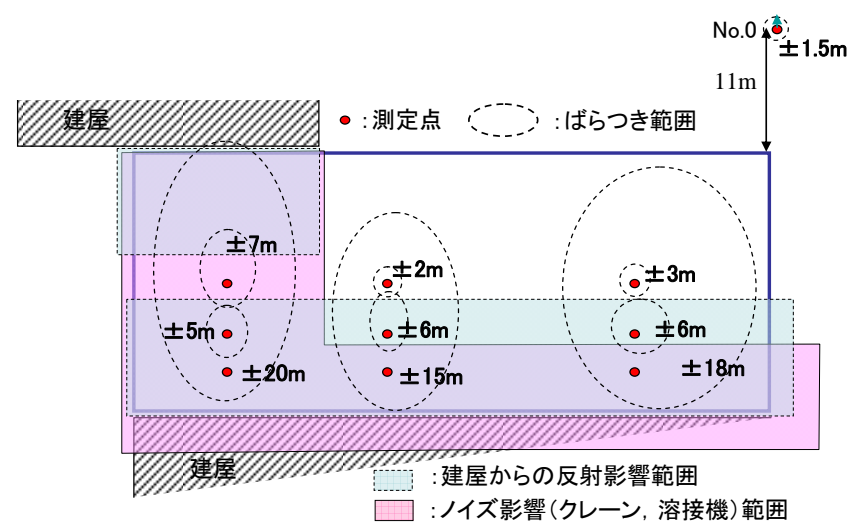

図 11 GPS 測定精度評価結果まとめ

\section{（3）資材管理システムの開発}

資材保管位置を記録・探索するためには，画面上に ビジュアルに製品保管位置が表示できることが有効と 考える. そこで，パソコンの画面上に建設現場の配置 図を読込み，GPS から取得した緯度・経度の絶対座標 を X-Y 座標に変換してマーキングし，探索する製品位 置や GPS 測定者の位置が容易に確認できるようにした

図 12 に機器構成と製品探索時の画面例を示す.機器 構成は PC 端末, RFID リーダ, 位置計測用の GPS アン テナの 3 つから成り, 一人で装備できるようにした. 仮置きした製品を探索する際には予め登録済みの製品 保管位置を呼び出し PC 端末画面に現場配置図上に測 定者の現在位置とあわせて表示した。

本システムを利用することで，広大な資材置場に製
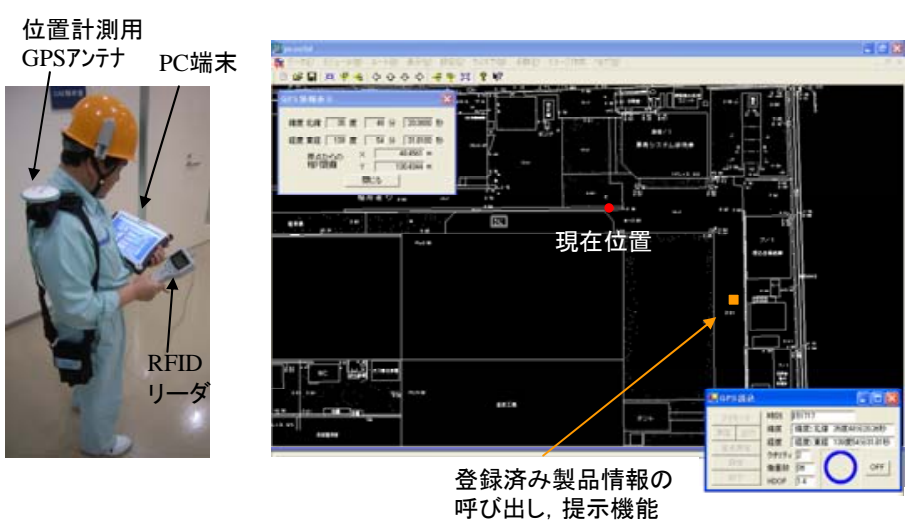

図 12 資材管理システム機器構成と製品探索画面
品を保管する際, 従来, ロープなどで区分けした範囲 での管理に比べ，より高精度に保管位置が記録でき， 製品探索時間が削減できると考える。 また，冬季に雪 が積もるような豪雪地方では保管した資材が雪に埋も れて見えなくなることもあり, 資材の探索がより難し い状況になる。このような現場では本 GPS のシステム が有効に活用できると考える.

\section{（4）写真管理システムの開発}

図 13 にRFID 応用写真管理システムの概要を示寸. 現場内で点検記録者と配管等の対象物の RFID を読取 り, デジタルカメラに RFID 情報を転送する. デジタル カメラ撮影機能により撮影した写真ファイルに RFID 読取機から転送された情報を埋め込むことで写真の真 贋証明を実現する。事務所に戻り, 撮影した写真ファ イルを RFID 情報と共にデータベースに登録すること で, RFID コードを用いて写真の整理, 検索が実現でき る. 以下，それぞれの機能について詳細を説明する.

\section{a）写真の真贋証明}

図 14 にRFID を利用した写真記録手順を示寸。点検記 録者は RFID リーダの付いた端末でヘルメット等につけ た本人特定用の RFID タグを読取る．次に検査結果を端 末に記録し，検査対象となる製品を特定する RFID タグ を読取る。端末内ではRFID が読取られた時刻 $\left(t_{0}\right)$ が記 録され，これ以降の経過時間を監視する. 写真撮影が行 われた時刻（ $\left.t_{1}\right)$ を確認し，RFID が読取られた時間から 写真撮影するまでの時間 $\left(t_{1}-t_{0}\right)$ が, 記録用端末内の不 正判断機能にて予め規定された撮影許可時間 $\left(t_{\mathrm{a}}\right)$ にお さまっているかを判定する。（ $\left.\mathrm{t}_{\mathrm{a}}\right)$ 内におさまっていな 場合, 読取った製品特定用の RFID タグ情報は削除され, 撮影した写真が無効となる。（ $\left.t_{\mathrm{a}}\right)$ 内におさまっている 場合, RFID タグの情報は写真の情報に埋め込まれて記録 される.この時, $\left(t_{\mathrm{a}}\right)$ は点検対象となる製品の RFID を読取った時刻から別な対象物や別な場所に移動して 写真を撮影することが不可能な時間に設定する．RFID 情報は唯一無二で，かつ読取った RFID の製品以外の撮 影を困難にすることで RFID 情報と記録写真内の被写体 の不一致を防ぎ，記録写真の真贋性が高まると考えた.

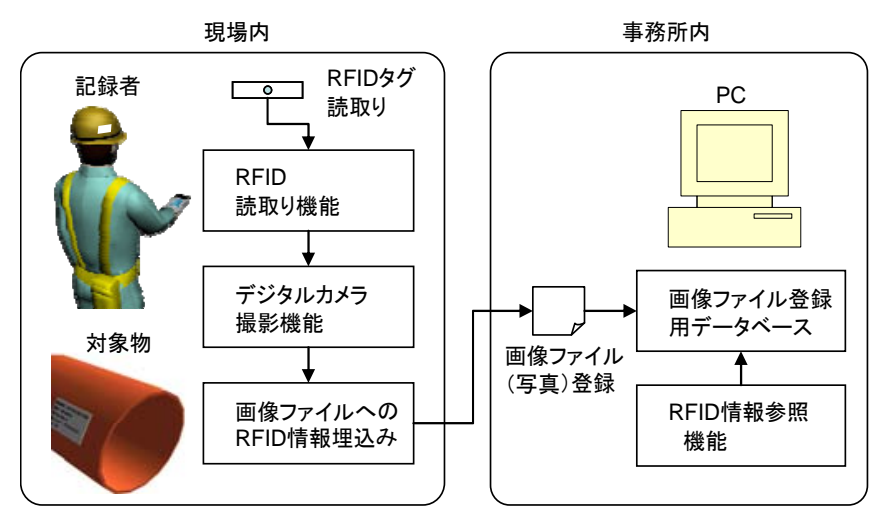

図 13 RFID 応用写真管理システム概要 


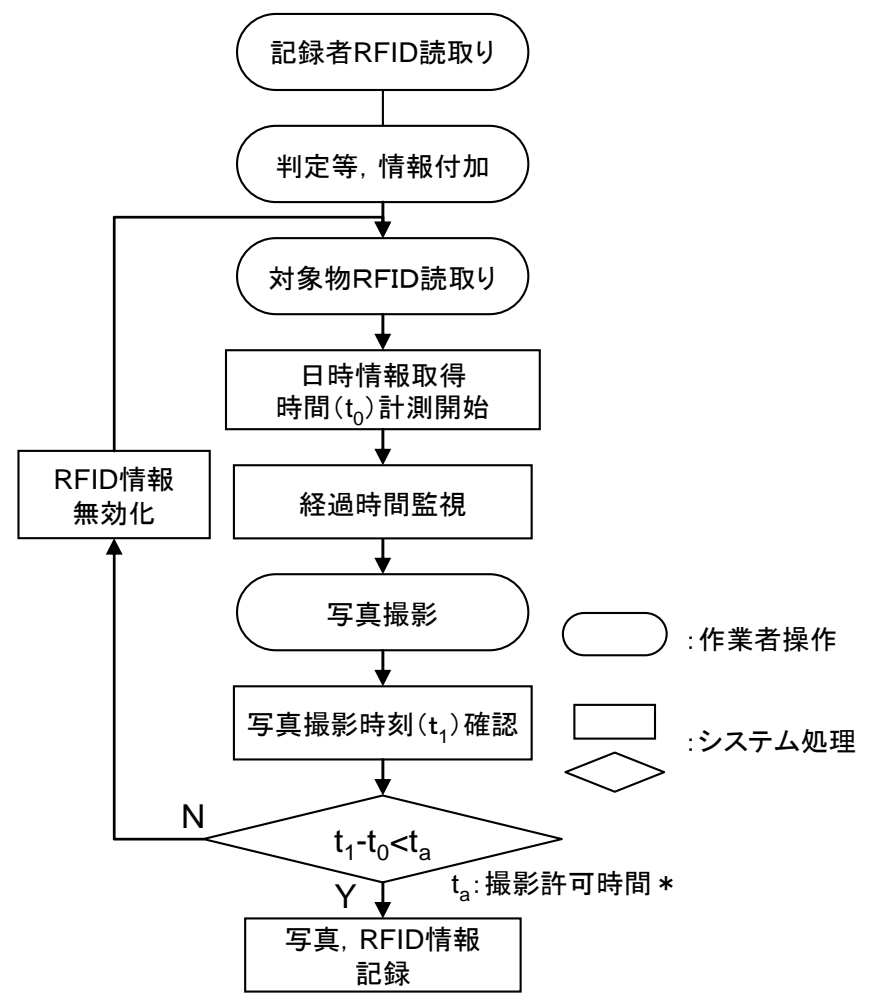

* 撮影許可時間: 写真を撮った時刻から遡り別な対象物や 別な場所に移動することが不可能な時間

図 14 RFID を利用した写真記録手順

\section{b）写真整理及び検索機能}

前述した真贋証明と写真の中身を自動判断するため に，写真ファイル内に RFID コードを埋め込む方法を検 討した. デジタルカメラで撮影する写真のフォーマット は規格化されている ${ }^{3)}$. 規格略称は Exif (Exchangeable image file format) と呼ばれ，写真ファイルに登録さ れる情報の種類や格納場所を規定している. 情報の種類 には画像サイズ, 解像度, 撮影条件等のほか, メ一カ名, カメラ型番, 緯度・経度等, オプション的条件もあり, それぞれ記載できる情報格納エリアが規定されている. この中にユーザ情報に関する格納エリアがあり, 読取っ た RFIDのコード情報を書き込むこととした。

Exif に書き込まれた情報はアプリケーションで参照 可能となる.画像のデータベースソフトを利用してExif のユーザ情報エリアに記録された RFID コードを参照し， あらかじめ RFID コードに紐付けられた記録者や配管等 の対象物に関する情報を参照できるシステムを構築し た.これにより, システム内に登録された写真は, ファ イルを開くことなく, 記録者や製品名等で検索ができる ようになる。

図 15 に RFID 応用写真管理システムの構成を示す. 本 システムは近距離無線通信規格のBluetooth 機能を相 互に備えた PDA（Personal Data Assistant）とデジタ ルカメラの組合せで構成される，検査記録の入力及び RFID 読取りをPDA にて行い, Bluetooth 通信によってデ

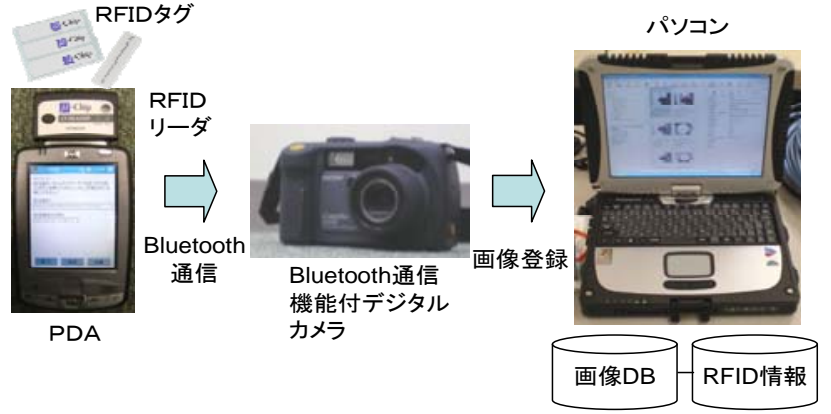

図 15 写真管理システム構成

ジタルカメラにリアルタイムにデータ転送する。図 14 で説明した撮影許可時間 $\left(t_{\mathrm{a}}\right)$ 内では読取った RFID 情報 が常時転送されるが, 撮影許可時間を過ぎると空の RFID 情報が転送され，それまでに転送していた RFID 情報を 消去する.デジタルカメラ側は PDA から送信された RFID 情報をExifユーザ情報エリアに書き込む機能を有する.

RFID コードが埋め込まれた写真を登録・管理するソフ トウェアには画像管理用ソフト（ImageServer2000）を 利用した。本ソフトで写真ファイルの Exif ユーザ情報 エリアに埋め込まれた RFID コードを参照し, 予めパソ コン内で設定した RFID コードと人や対象物との紐付け 情報に基づき写真の検索や帳票作成機能を実現した。

図 16 にRFID 応用写真管理システム利用状況を示す. 図 17 にはPDA の画面遷移を示す.ソフトを起動すると ユーザ認証画面が表示され, 点検者の RFID 読取りを促 す. 点検者はヘルメットに張付けられた本人認証用 RFID タグを読取る（a）. 次に点検結果入力画面にて, 点検結果として良否判定を行い（b），撮影準備ボタン を押すと RFID リーダが読取り状態になる. 対象となる 配管に貼り付けられた RFID を読取ると同時に,データ 転送画面 (c) のようにタグの読取り時刻を保持しなが らデジタルカメラに RFID コード及び点検結果を転送 する.デジタルカメラ側では図 16 のようにカメラの液 晶面に転送された RFID コードが表示され, データ転送 状況が確認できる.この状態で点検写真を撮影すると 写真ファイル内の Exif ユーザ情報エリアに RFID コー ド及び点検結果が埋め込まれる.

図 18 に写真管理用データベースソフトの画面を示す.
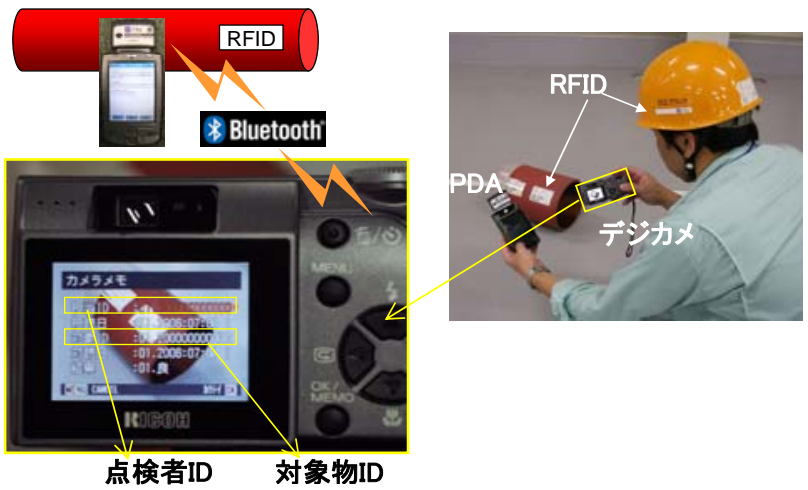

図 16 システム利用状況 


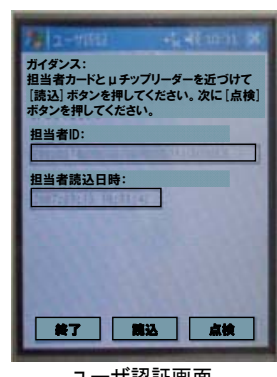

ユーザ認証画面

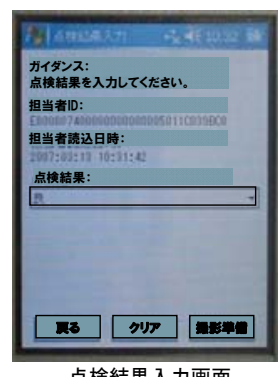

点検結果入力画面

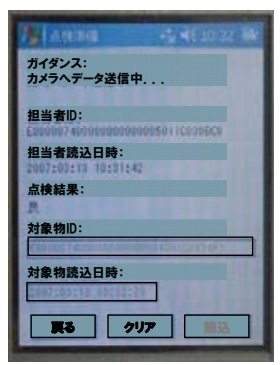

データ転送画面
図 17 PDA 画面遷移図

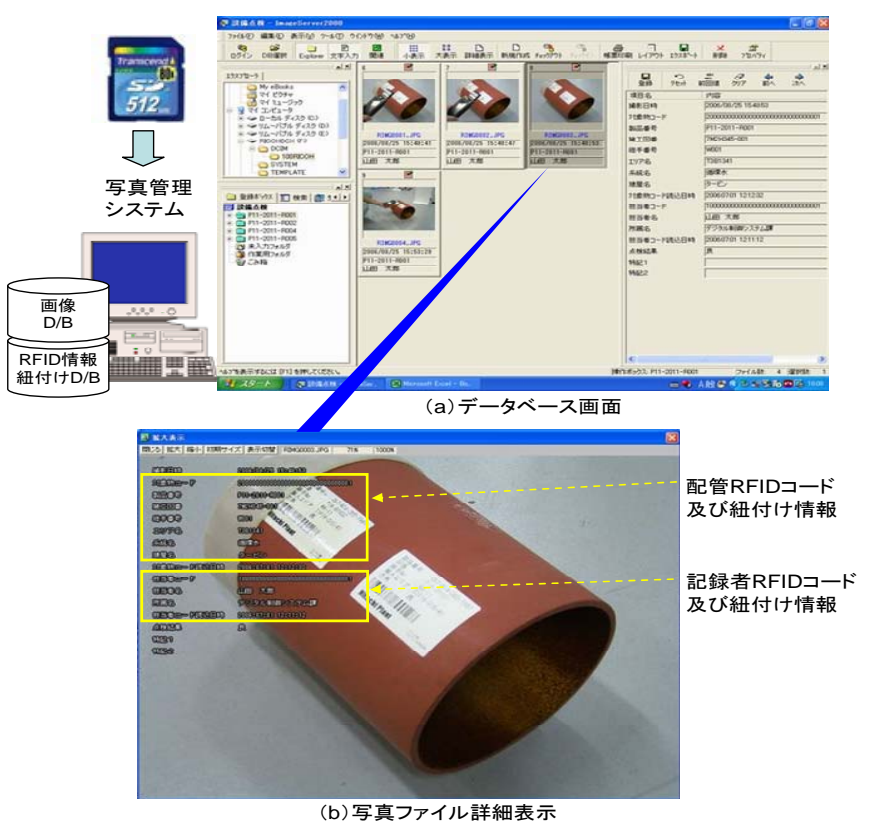

図 18 写真管理用データベースソフト画面

撮影した写真はメモリカードに記録される. メモリカードに 記録された写真ファイルを画像データベースに登録する。 データベースソフト内には点検記録者の RFID コードに対 する所属と名称, 配管の RFID コードに対する図面番号, 溶接点番号, 系統名等が予め紐付けられて記録されおり 写真ファイルを登録すると共に, Exif ユーザ情報エリアか ら RFID 情報を呼び出し, 関連情報を表示させる. 写真つ アイルの詳細を表示する時(図 18 (b) ) には, これらの情 報を画面上に表示するようにした。

\section{c) 効果検証}

RFID コードは唯一無二であるため配管に RFID を取 付ける際に間違いがなければ RFID コードによって対 象配管は一意に特定できる。これにより, 対象物の RFID コードが間違いなく写真に埋め込まれれば写真 の真贋性が証明できると考える.

被写体の対象物と RFID コードを間違いなく紐付け るために, 本システムでは RFID 読取りから規定の時間 内に撮った写真にのみ RFID を記録する仕組みとした. この撮影可能時間として 30 秒を設定して検証した. 現 場環境を模擬した環境下で, RFID 情報を読み取ってか ら対象物を撮影するのに 30 秒あれば可能であった.し かし，RFID 情報を読取ってから別の対象物を撮影する
には, 移動時間を含めると 30 秒では困難であった. プ ラント建設のように比較的製品サイズが大きく対象物 が広範囲に配置される場合, RFID 情報を写真に転送す る時間を制限することで，写真の真贋性は高まると考 える.しかし小径配管等においては近接した配管も存 在することから, すべての対象物に対し, 写真の真贋 性を $100 \%$ 保証するのは困難であった。今後, 実運用 と合せて真贋証明可能な範囲を確認してゆく.

記録写真を撮影寸るには，従来，現場にて製品情報 をボードに記載する作業に変わり，点検記録者と製品 に貼付けられた RFID から情報を読取るだけとなり，現 場での作業工数は同等以下と考える. 更に, 事務所で 写真を整理する際は, 従来, 撮影してきた写真を人が 確認しながら整理し, 半日の異物検査作業に対し $2 \sim 3$ 時間を掛けて帳票化していた。本システムを利用する ことで写真の探索と帳票作成が自動化され 2〜3 時間 の作業を 30 分程度に短縮できることが確認できた.

\section{5. まとめ}

プラント建設における工事の管理業務効率化を目的 に，RFID の適用性評価及び RFID 応用アプリケーショ ンの開発を行い, 以下の結論を得た。

- RFID の耐環境性能評価項目として, 溶接熱影響な ど，現地模擬環境下にて読取り試験を実施し，実 運用上問題ないことを確認した.

- 資材保管位置記録に利用寸る GPS は，建屋近傍や 溶接機やクレーン等のノイズ環境下では誤差が大 きく適用困難であるが，広大な資材置場での保管 位置記録には有効であることを確認した。

・ 記録写真の真贋性を高める方法としてRFID 情報を 写真ファイル内に組み込むこと，及びその際の RFID 情報転送時間を制限する方法を提案した。

・写真管理用のデータベースシステムにより, RFID 情報から対象物を自動的に呼び出すことで帳票作 成を自動化できるようにした。

現在，開発したシステムの実運用を開始している。し かし RFID 等の基盤技術はまだまだ改良の余地がある. 新製品の検証と共にアプリケーションの応用を継続し て進めて行く.

\section{参考文献}

1) 芦川栄晃, 指田吉雄: 近距離無線応用による現場作業の効 率化:計装, 47(3), 2004 年

2) 志谷倫章, 矢吹信喜：IC タグを用いた現場デジタル写真 および設計情報管理システム，土木情報利用技術論文集， Vol.14, pp.59-66, 2005 年.

3) ディジタルスチルカメラ技術専門委員会 : JEIDA 規格デ イジタルスチルカメラ用画像ファイルフォーマット規格 （Exif）Version2.1：（社）日本電子工業振興会，1998 年 